\title{
Antimicrobial Activity of Thyme and Rosemary Oils against Pseudomonas aeruginosa Strains
}

\author{
Kekik ve Biberiye Yağlarının Pseudomonas aeruginosa Suşları \\ Üzerine Antimikrobiyal Etkileri
}

\author{
Research Article
}

Sinem Diken Gür*, Sezen Bilen Özyürek, Işıl Seyis Bilkay

Hacettepe University, Faculty of Science, Department of Biology, Beytepe, Ankara, Turkey.

\section{A B S TR AC T}

$\mathrm{N}$ owadays, a remaining scientific interest is exhibited to the antimicrobial effect of essential oils, due to their unique and complex biological potential. In this study, owing to the significance of the essential oils, investigating the antimicrobial properties of thyme and rosemary oils against 8 different Pseudomonas aeruginosa strains which have different antibiotic resistance patterns was aimed. For this purpose, antibiotic resistance analysis was carried out with 11 different antibiotics by Kirby Bauer Disc Diffusion method and it was found that the strains were resistant to trimethoprim/sulfamethoxazole, tetracycline 100\%; aztreonem, meropenem, imipenem 50\%; on the other hand, the strains were sensitive to piperacillin, ceftazidime and amicasin. As a result of determination of antimicrobial potential of the essential oils, the thyme oil was found to be very effective as an antimicrobial agent but the rosemary oil was effective only two $P$. aeruginosa strains. While thyme oil was found to be more effective at high concentration (1/2), antimicrobial effect was detected even at the lowest concentration (1/20). Although there are some studies concerning about essential oils' antimicrobial effectiveness on multidrug $P$. aeruginosa in literature, this study differs from others because of the thyme oil has been found to be very effective to multidrug resistant $P$. aeruginosa strain (P5) which was resistant to 8 different antibiotic groups. Consequently, this study signalizes that with the antimicrobial effect of thyme oil, it could be used for the treatment of MDR P. aeruginosa infections in the near future.

\section{Key Words}

Pseudomonas aeruginosa, Thyme oil, Rosemary oil, Antimicrobial activity.

\section{öz}

ünümüzde, esansiyel yağların antimikrobiyal etkilerine, özgün ve kompleks biyolojik potansiyelleri nedeniyle

$\mathcal{J}$ artan bir ilgi söz konusudur. Bu çalışmada esansiyel yağların önemi nedeniyle farklı antibiyotik direnç paternleri olan 8 farklı Pseudomonas aeruginosa suşuna karşı kekik ve biberiye yağlarının antimikrobiyal özelliklerinin araştırılması amaçlandı. Bu amaçla Kirby Bauer disk difüzyon yöntemi ile 11 antibiyotik için antibiyotik direnç analizi gerçekleştirildi. Suşlar \%100 trimetoprim/sülfometaksazol ve tetrasiklin, \%50 aztreonam, meropenem, imipenem dirençli olarak bulundu; diğer yandan suşlar piperasilin, seftazidim ve amikasine duyarlıdır. Esansiyel yağların antimikrobiyal potansiyellerinin belirlenmesi sonucunda, kekik yağı antimikrobiyal ajan olarak çok etkili bulundu. Fakat biberiye yağının yalnız iki $P$. aeruginosa suşuna etkili olduğu görüldü. Kekik yağı yüksek derişimlerde (1/2) daha etkili olarak bulunurken düşük derişimlerde (1/20) bile antimikrobiyal etki belirlendi. Literatürde esansiyel yağların çoklu ilaç dirençli $P$. aeruginosa üzerindeki antimikrobiyal etkinlikleri ile ilgili bazı çalışmalar olmasına rağmen bu çalışma kekik yağının 8 farklı antibiyotik grubuna dirençli olan çoklu ilaç dirençli $P$. aeruginosa suşuna karşı çok etkili bulunması nedeniyle diğerlerinden farklıdır. Sonuç olarak bu çalışma kekik yağının antimikrobiyal etkisi ile yakın gelecekte çoklu ilaç dirençli $P$. aeruginosa infeksiyonlarının tedavisi için kullanılabileceğini gösteriyor.

\section{Anahtar Kelimeler}

Pseudomonas aeruginosa, Kekik yağı, Biberiye yağı, Antimikrobiyal aktivite.

Article History: Received: Mar 17, 2017; Revised: Jul 19, 2017; Accepted: Oct 9, 2017; Available Online: Dec 25, 2017. DOI: $10.15671 / \mathrm{HJBC} .2018 .185$

Correspondence to: S.D. Gür, Hacettepe University, Faculty of Science, Department of Biology, Beytepe, Ankara, Turkey. 


\section{INTRODUCTION}

Seudomonas aeruginosa is a gram-negative pathogen that causes a variety of serious infections predominantly in immunocompromised and inpatients [1,2]. However, nosocomial infections caused by multidrug resistant $P$. aeruginosa (MDR) present a very serious problem for the control of clinical infections in recent years [3]. Due to the presence and increase of numerous drug-resistant strains an instant need occurs in order to develop novel antimicrobial agents [4]. In recent years, due to the instruction about the treatment effect of plants used in folk remedy was published by World Health Organization, in developing countries researches which are related to complementry and alternative medicine are increasingly getting more important [5]. Nowadays, determining the antimicrobial activity of essential oils acquired from plants becomes more of an issue in order to discover new antimicrobial agents against multidrug resistant strains $[6,7]$. Because of the antimicrobial activity and activation of digestive system of essential oils that are extracted from spices, they are getting more important [8]. Owing to the antiparasitic, anthelmintic, antiseptic, antidiabetic anelgesic expectorant and tranquilizer properties of these essential oils, they are traditionally used in many parts of the world [9]. In addition to this, essential oils have biological activities such as antioxidant and hypercholesterolemia [10]. Because of these potential antimicrobial effects of essential oils, we aimed to research the antimicrobial activity of thyme and rosemary oils against $P$. aeruginosa which have different antibiotic resistance patterns in our study.

\section{MATERIALS and METHODS}

Essential oils: In the present study essential oils, which were extracted from Thymus vulgaris (thyme oil) and Rosmarinus officinalis (rosemary oil), were provided from a herbal store in Ankara, Turkey.

Bacterial strains: In this study, $8 P$. aeruginosa strains isolated from different clinical materials were used. These strains were cultured onto nutrient and EMB (Eozin-Methylen Blue) agar. After that non-lactose fermented colonies were selected and cultured onto Cetrimide agar, which is selective and differentiating media for $P$. aeruginosa, and incubated overnight at $37^{\circ} \mathrm{C}$. Then selected colonies were identified [11].

Antimicrobial assay (Disc Diffusion Assay): $P$. aeruginosa strains were also evaluated for their susceptibilities towards 11 different antimicrobial agents by Kirby Bauer Disc Diffusion method [12].

\section{Determination of antimicrobial activity of the} essential oils: In order to detect the antimicrobial effect of essential oils, "Agar Well Diffusion" method was carried out [13]. For this purpose, the bacterial isolates were cultured overnight at $37^{\circ} \mathrm{C}$ on Brain Heart Infusion Broth. Bacterial cultures were diluted in sterile saline solution $(0.09 \% \mathrm{NaCl})$ and the optical density (OD 600) was adjusted according to the tube 0.5 of McFarland turbidity to prepare a standardized inoculum with UVVisible Spectrophotometer (Shimadzu-UV 1700) $\left(1.5 \times 10^{8} \mathrm{CFU} / \mathrm{ml}\right)$. Afterwards, petri dishes with $20 \mathrm{ml}$ of Mueller Hinton Agar, which contain of 1 $\mathrm{mL}$ bacterial culture suspension, were prepared. Following the solidification of medium, wells with $7.0 \mathrm{~mm}$ diameter extend were created. In addition to this, each essential oil (thyme and rosemary) was diluted in methanol to the test concentration $(1 / 2,1 / 5,1 / 8,1 / 10,1 / 15$ and $1 / 20)$, was added into wells $(25 \mu \mathrm{l})$ for each test microorganism and same volume $(25 \mu \mathrm{l})$ of methanol was used as a control. The inoculated plates were incubated at $37^{\circ} \mathrm{C}$ for $24 \mathrm{~h}$. After incubation, the diameters of the bacterial inhibition zones were measured.

\section{RESULTS}

In this study, antibiotic patterns of clinical $P$. aeruginosa strains were determined by disc diffusion method for 11 different antibiotics (Table 1).

Antibiotic susceptibilities of $P$. aeruginosa strains were indicated in Table 2. When the antibiotic susceptibilities of $P$. aeruginosa strains were examined, it was found that P5, which was resistant to all antibiotics, was the most resistant $P$. aeruginosa strain in our study (Table 2 ).

When the antimicrobial effects of essential oils 
Table 1. The codes, content of discs and zone diameters of antibiotics.

\begin{tabular}{|c|c|c|c|c|c|}
\hline \multirow[t]{2}{*}{ Antibiotics } & \multirow[t]{2}{*}{ Code } & \multirow[t]{2}{*}{ Content of disc } & \multicolumn{3}{|c|}{ Zone diameter (mm) } \\
\hline & & & $\mathrm{R}$ & 1 & $\mathrm{~S}$ \\
\hline Aztreonam & ATM & $30 \mu \mathrm{g}$ & $\leq 15$ & $16-21$ & $\geq 22$ \\
\hline Piperacillin & PIP & $10 \mu \mathrm{g}$ & $\leq 17$ & - & $\geq 18$ \\
\hline Ceftazidime & CAZ & $30 \mu \mathrm{g}$ & $\leq 14$ & $15-17$ & $\geq 18$ \\
\hline Cefepime & FEP & $30 \mu \mathrm{g}$ & $\leq 14$ & $15-17$ & $\geq 18$ \\
\hline Meropenem & MEM & $10 \mu \mathrm{g}$ & $\leq 13$ & $14-15$ & $\geq 16$ \\
\hline Imipenem & IMP & $10 \mu \mathrm{g}$ & $\leq 13$ & $14-15$ & $\geq 16$ \\
\hline Ciprofloxacin & CIP & $5 \mu \mathrm{g}$ & $\leq 15$ & $16-20$ & $\geq 21$ \\
\hline Amikacin & AN & $30 \mu \mathrm{g}$ & $\leq 14$ & $15-16$ & $\geq 17$ \\
\hline Tobramycin & NN & $10 \mu \mathrm{g}$ & $\leq 12$ & $13-14$ & $\geq 15$ \\
\hline $\begin{array}{c}\text { Trimethoprim/ } \\
\text { Sulfomethoxazole }\end{array}$ & TMP/SXT & $1.25 / 23.75 \mu \mathrm{g}$ & $\leq 10$ & $11-15$ & $\geq 16$ \\
\hline Tetracycline & TE & $30 \mu \mathrm{g}$ & $\leq 14$ & $15-18$ & $\geq 19$ \\
\hline
\end{tabular}

R: Resistant I: Intermediate S: Sensitive

Table 2. Antibiotic susceptibility patterns of Pseudomonas aeruginosa strains.

\begin{tabular}{|c|c|c|c|c|c|c|c|c|c|c|c|}
\hline & ATM & PIP & CAZ & FEP & MEM & IMP & CIP & AMK & NN & $\mathrm{TMR} / \mathrm{SXT}$ & $\mathrm{Te}$ \\
\hline $\mathrm{P} 1$ & $\mathrm{R}$ & S & $S$ & $\mathrm{R}$ & $\mathrm{R}$ & $\mathrm{R}$ & $S$ & $S$ & $\mathrm{R}$ & $\mathrm{R}$ & $\mathrm{R}$ \\
\hline P2 & $S$ & S & $S$ & $S$ & $S$ & $S$ & $S$ & $S$ & $S$ & $\mathrm{R}$ & $\mathrm{R}$ \\
\hline P3 & $S$ & $S$ & $S$ & $S$ & $S$ & $S$ & $S$ & S & S & $\mathrm{R}$ & $\mathrm{R}$ \\
\hline P4 & $\mathrm{R}$ & S & S & $S$ & $\mathrm{R}$ & $S$ & $S$ & S & S & $\mathrm{R}$ & $\mathrm{R}$ \\
\hline P5 & $\mathrm{R}$ & $\mathrm{R}$ & $\mathrm{R}$ & $\mathrm{R}$ & $\mathrm{R}$ & $\mathrm{R}$ & $\mathrm{R}$ & $\mathrm{R}$ & $\mathrm{R}$ & $\mathrm{R}$ & $\mathrm{R}$ \\
\hline P6 & $\mathrm{R}$ & S & $S$ & $S$ & $S$ & $\mathrm{R}$ & $S$ & $S$ & $S$ & $\mathrm{R}$ & $\mathrm{R}$ \\
\hline P7 & $S$ & $S$ & $S$ & $S$ & $S$ & $S$ & $S$ & $S$ & $S$ & $\mathrm{R}$ & $\mathrm{R}$ \\
\hline P8 & $\mathrm{R}$ & $S$ & $S$ & $\mathrm{R}$ & $\mathrm{R}$ & $\mathrm{R}$ & $\mathrm{R}$ & $S$ & $\mathrm{R}$ & $\mathrm{R}$ & $\mathrm{R}$ \\
\hline
\end{tabular}

P1-P8: P. aeruginosa strains.

ATM: Aztreonam, PIP: Piperacillin, CAZ: Ceftazidime, FEP: Cefepime, MEM: Meropenem,

IMP:Imipenem, CIP: Siprofloxacin, AMK: Amicasin, TOB: Tobramycin, TMP/SXT: Trimethoprim/Sulfamethoxazole, Te: Tetracycline.

were assayed in different concentrations, it was determined that the thyme oil was found to be very effective as an antimicrobial agent (Table 3).

As well as, thyme oil indicated the highest antimicrobial activity against the one of the multidrug resistant $P$. aeruginosa strain which was resistant to 11 different antibiotics. When the antimicrobial activities according to different thyme oil concentrations have been examined, the thyme oil at $1 / 2$ concentrain in absolute methanol was found to be the most effective concentration to all $P$. aeruginosa strains. In addition to this, thyme oil was effective to multidrug resistant $P$. aeruginosa even at the lowest concentration (1/20) (Table 3). On the other hand, it was indicated that the rosemary oil was effective against only two $P$. aeruginosa strains (Table 4). 
Table 3. The inhibition zones obtained with thyme oil against $P$. aeruginosa strains.

\begin{tabular}{|c|c|c|c|c|c|c|}
\hline & $\mathrm{T}(1 / 2)$ & $\mathrm{T}(1 / 5)$ & $\mathrm{T}(1 / 8)$ & $\mathrm{T}(1 / 10)$ & $\mathrm{T}(1 / 15)$ & $T(1 / 20)$ \\
\hline $\mathrm{P} 1$ & 14 & 14 & 13 & 13 & 13 & 12 \\
\hline P2 & 15 & 15 & 15 & 14 & 14 & 12 \\
\hline P3 & 16 & 14 & 12 & 12 & 12 & 11 \\
\hline P4 & 15 & 13 & 12 & 12 & 12 & 12 \\
\hline P5 & 20 & 19 & 18 & 15 & 15 & 15 \\
\hline P6 & 15 & 14 & 12 & 12 & 0 & 0 \\
\hline P7 & 15 & 14 & 14 & 14 & 14 & 13 \\
\hline P8 & 13 & 13 & 11 & 11 & 10 & 10 \\
\hline
\end{tabular}

The inhibition zone in diameters $(\mathrm{mm})$.

Dilution ratios of thyme oil: $1 / 2,1 / 5,1 / 8,1 / 10,1 / 15,1 / 20$.

Table 4. The inhibition zones obtained with rosemary oil against $P$. aeruginosa strains.

\begin{tabular}{ccccccc}
\hline & $\mathrm{R}(1 / 2)$ & $\mathrm{R}(1 / 5)$ & $\mathrm{R}(1 / 8)$ & $\mathrm{R}(1 / 10)$ & $\mathrm{R}(1 / 15)$ & $\mathrm{R}(1 / 20)$ \\
\hline $\mathrm{P} 1$ & 13 & 0 & 0 & 0 & 0 \\
\hline P2 & 0 & 0 & 0 & 0 & 0 & 0 \\
\hline P3 & 0 & 0 & 0 & 0 & 0 & 0 \\
\hline P4 & 0 & 0 & 0 & 0 & 0 & 0 \\
\hline P5 & 0 & 0 & 0 & 0 & 0 & 0 \\
\hline P7 & 13 & 13 & 11 & 0 & 0 \\
\hline P8 & 0 & 0 & 0 & 0 & 0 & 0 \\
\hline
\end{tabular}

The inhibition zone in diameters $(\mathrm{mm})$.

Dilution ratios of rosemary oil: 1/2,1/5, 1/8, 1/10,1/15, 1/20.

\section{DISCUSSION}

Because of the increasing antibiotic resistance in $P$. aeruginosa strains, which are the main agent of hospital acquired infections, we need new antimicrobial agents for treatment. Due to the development of antibiotic resistance in microorganisms, researchers are aimed to discover more effective antimicrobial drugs [7]. The antimicrobial activities of essential oils are based on a number of small terpenoids and phenolic compounds (thymol, carvacrol and eugenol), which, they consist, indicate high antimicrobial activity in pure form [14]. The most important characteristic of essential oils and their components is their hydrophobicity, which allow them to interact with the lipids of the bacterial cell membrane and mitochondria, disturbing the structure of cell membrane to effect its permeability. As a result, this loss of important molecules and ions from bacterial cells will lead to death. Moreover, some compounds also cause drug resistance in several gram-negative bacteria by targeting efflux mechanisms [15-17].

The antimicrobial effectiveness of essential oils are classified as strong, medium and weak [18]. Particularly cinnamon, clove, pimento, thyme, oregano and rosemary herbs have high antimicrobial activity [19]. For this reason, in the present study thyme and rosemary oils were tested for their antimicrobial activities against the Pseudomonas aeruginosa strains which have different antibiotic resistance patterns. For this purpose, antibiotic susceptibilities profiles of 8 $P$. aeruginosa strains were determined with 11 different antibiotics (Table 2). When the antibiotic susceptibilities of $P$. aeruginosa strains were analyzed, all strains in this study were resistant to 
trimethoprim/sulfamethoxazole and tetracycline. Similar to our study, 7 different $P$. aeruginosa strains were resistant to trimethoprim/ sulfamethoxazole [20]. Multi-drug efflux systems in $P$. aeruginosa strains display high resistance to trimethoprim/sulfamethoxazole and it was shown that mexABoprM efflux system is primarily responsible for the intrinsic resistance of $P$. aeruginosa strains to these synthetic antibacterial agents [21].

Due to the fact that it does not have a cross-allergic reaction with the antibiotics such as penicillin and cephalosporin (except from ceftazidime) and is not inhibited by metallo-beta lactamases the aztroenam is frequently used in the treatments of $P$. aeruginosa infections [2224]. However, the aztreonam resistance ratios of the $P$. aeruginosa strains used in our study are found to be a very high ratio as $50 \%$. It is thought that this high aztreonam resistance ratio seen in the $P$. aeruginosa strains results from the fact that the resistant strains transfer their resistance gene to the sensitive strains. Moreover, the ability of microorganisms that produce ESBL and-or AmpC type enzymes to hydrolyze wide-spectrum cephalosporins is one of the most important reasons for the increase in the aztreonam resistance. Similar with the other studies carried out in this field, high aztreonam resistance was seen $[25,26]$.

Although carbapenems are the main antibiotics that are used for the treatments of the infections that are caused by the $P$. aeruginosa strains which have multi-drug resistance, the resistance has considerably decreased in recent years. For this reason, imipenem and meropenem antibiotics from the carbapenem group were included in our study; however, the resistance of the $P$. aeruginosa strains to these antibiotics was found to be notably high. The carbapenem resistance of $P$. aeruginosa has generally multifactors especially in the cases that there are no enzymes such as metallo-beta lactamases that hydrolyze carbapenems [27]. Low external membrane permeability, the activities of MexABOprM efflux pumps, inducible or depressed chromosomal AmpC beta-lactamases and penicillin-binding protein PBP-5 have significant roles in the development of carbapenem resistance [28].

On the other hand, while OprD porin loss has a significant role in the imipenem resistance increasing in $P$. aeruginosa, its effect on the meropenem resistance is lower. Moreover, Although the over-expression of the MexABOprM efflux system does not have any effect on the imipenem due to its meropenems' 2' heterocyclic side chain structure, it is known that it reduces the effectiveness of the meropenems. Even, MexCD-OprJ and MexXY-OprM efflux systems contribute in the meropenem resistance $[29,30]$. Although it is known that the resistance development of the meropenem that is one of the carbapenem group antibiotics is more complex than the resistance development of the imipenems and the meropenems are more effective than the imipenems in vitro studies, no significant difference between the imipenems and meropenems in terms of effectiveness was found in our study [31].

Aminoglycosides have a significant place for the treatment of the $P$. aeruginosa infections. For this purpose, it was seen that the amicasin antibiotic included in our study was effective on $8 P$. aeruginosa strains. Amikacin among the aminoglycosides is more effective against the $P$. aeruginosa strains due to its being affected by less aminoglycoside modifying enzymes and its resistance development is less. Similar with the other studies carried out in this field, the amikacin susceptibility was found considerably high $[32,33]$.

After the antibiotic susceptibility patterns of the $P$. aeruginosa strains used in our study were determined, antimicrobial activities of the essential oils were researched. It was determined that the antimicrobial activities of thyme and rosemary oils used for this purpose were different. Due to the fact that essential oils vary from according to the herb type whose chemical compositions are extracted from, the antimicrobial activities of these oils were found different from each other. Even their chemical contents show changes according to the extraction technique of the essential oils obtained from the same 
herb species, geographical region where the herbs are collected, the maturation period of the herbs [34]. When the bacterial inhibition zone diameters of essential oils were investigated, it was found that the thyme oil was very effective as an antimicrobial agent. According to different studies similar to our study; thyme oil has been found to be effective as an antimicrobial agent, 10-15 and 15-20 $\mathrm{mm}$ zone diameters have also been observed $[35,36]$. In another study, the inhibition zone diameters have been formed as approximately 30-40 $\mathrm{mm}$ for $P$. aeruginosa [37].

When the antimicrobial activities of thyme oil according to different concentrations have been examined, the thyme oil at $1 / 2$ concentration in absolute methanol was found as the most effective concentration. Similar to our study, excessive concentrations of thyme oil were significantly more effective as an antimicrobial agent [38]. In contradistinction to our study, it was indicated that the lowest concentration (1\%) of thyme oil was found to be more effective [39].

Rosemary oil was found to be effective against only $2 P$. aeruginosa strains in high concentrations as distinct from thyme oil. According to another study similar to ours, inhibition zones of about 10 $13 \mathrm{~mm}$ were recorded for the high concentration of the rosemary oil [35]. Another contrast studies, the bacterial growth inhibition effect of rosemary oil was not determined $[40,41]$. This variation in antimicrobial activities reported in the different investigations could be based on some ecological factors related with plant species or the use of the active principle compounds.

There are researches in the literature about the effects of the essential oils on the multidrug resistant $P$. aeruginosa strains. Because of improving effective agents against multi drug resistant pathogens is getting important therefore an alarming increase in antimicrobial resistance. In recent studies, multi-drug resistance has been identified as being resistant to at least three of the antibiotic groups which are aminoglycosides, antipseudomonal penicillins, cephalosporins, carbapenems and fluoroquinolones [42]. According to this identification, multi-drug resistance was determined in 3 of the strains used in our study. It was determined that among the essential oils used in our study, thyme oil was the most effective against MDR $P$. aeruginosa strain that was resistant to all antibiotics used in the study (Table 2 and Table 3). In the study carried out in a similar way with our study, it was determined that the thyme oil was effective on different MDR $P$. aeruginosa strains and could be used for the treatments of serious infections [37]. Moreover, it was stated that multidrug resistant P1 strain was one of the strains that affected from rosemary oil (Table 2 and Table 4). According to different study which is similar to our study, rosemary oil was seen to be more active toward drug resistant strains of some bacteria than the susceptible ones [41]. Like our study, Zampini and friends are determined that rosemary oil affected multidrug resistant $P$. aeruginosa strains [43]. In spite of the high resistance development against the antibiotics used frequently in clinic, due to the fact that the strains are sensitive to the essential oils the issue has been thought that the antimicrobial effect mechanism of essential oils might be different from conventional antibiotics. Although there are some studies concerning about the antimicrobial activity of thyme and rosemary oils in the literature, this study differs from others because of the thyme oil has been found to be very effective to multidrug resistant $P$. aeruginosa strain (P5) which was resistant to 8 different antibiotic groups. As a result of this study, even low concentrations of thyme oil were found to be effective toward multi drug resistant strains of $P$. aeruginosa as intended in our study. For this reason, it is thought that the antimicrobial effect mechanisms of the essential oils are different from the antibiotics.

\section{CONCLUSION}

The data obtained from the study reveal that treatment for multidrug resistant $P$. aeruginosa strains can be carried out with essential oils in the near future. As a result of this, hospital acquired infections caused by multi drug 
resistant $P$. aeruginosa isolates can be prevented effectively. But in order to use thyme oil for the treatment of hospital acquired infections, further investigations regarding the in vitro and in vivo toxicity should be conducted.

\section{References}

1. C.M. Shaver, A.R. Hauser, Relative contributions of Pseudomonas aeruginosa ExoU, ExoS, and ExoT to virulence in the lung, Infec. Immun., 72 (2004) 696977.

2. M.D. Obritsch, D. Marilee, D.N. Fish, R. MacLaren, R. Jung, Nosocomial infections due to multidrugresistant Pseudomonas aeruginosa: Epidemiology and treatment options, Pharmacother., 25 (2005) 1353-64.

3. D. Fang, X. Xi-wei, S. Wen-qi, L. Ping, Y. Sang-jie, Y. Yong-hong, S. Xu-zhuang, Characterization of multidrug-resistant and metallo-betalactamaseproducing Pseudomonas aeruginosa isolates from a paediatric clinic in China, Chin. Med. Sci. J., 121 (2008) 1611-16.

4. T.S. Naimi, K.H. LeDell, D.J. Boxrud, A.V. Groom, C.D. Steward, S.K. Johnson. Epidemiology and clonality of community-acquired methicillin resistant Staphylococcus aureus in Minnesota, 1996-1998, Clin. Infect. Dis., 33 (2001) 990-96.

5. T.A. Ibrahim, B.O. Opawale, J.M.A. Oyinloye, Antibacterial activity of herbal extracts against multi drug resistant strains of bacteria from clinical origin, Life Sci. Leaflets., 15 (2011) 490-98.

6. L. Jirovetz, G. Buchbauer, M.B. Ngassoum, J.J. Essia-Ngang, L.N. Tatsadjieu, O. Adjoudji, Chemical composition and antibacterial activities of the oils of Plectranthus glandulosus and Cinnamomum zeylanicum from Cameroon, Sci. Pharm., 70 (2002) 93-99.

7. L.C. Braga, A.A.M. Leite, K.G.S. Xavier, J.A. Takahashi, M.P. Bemquerer, E. Chartone-Souza, A.M.A. Nascimento, Synergic interaction between pomegranate extracts and antibiotics against Staphylococcus aureus, Can. J. Microbiol., 51 (2005) 541-47.

8. S. Rahman, A.K. Parvez, R. Islam, M.H. Khan, Antibacterial activity of natural spices on multiple drug resistant Escherichia coli isolated from drinking water, Bangladesh, Ann. Clin. Microbiol. Antimicrob. 10 (2011) 1-4.

9. K.W. Lee, H. Everts, A.C. Beynen, Essential oils in broiler nutrition, Int. J. Poult. Sci., 3 (2004) 738-52.

10. K. Miura, H. Kikuzaki, N. Nakatani, Antioxidant activity of chemical components from sage (Salvia officinalis L.) and thyme (Thymus vulgaris L.) measured by the oil stability index method, J. Agric. Food Chem., 50 (2002) 1845-51.

11. C.R. Mahon, J.M. Manuselis, Textbook of diagnostic microbiology, $2^{\text {nd }}$ edition, Saunders, W.B., Philadelphia, (2000) 540-54 pp.

12. S.M. Finegold, E.J. Baron, Methods for testing antimicrobial effectiveness, Diagnostic Microbiology. 7th Edition, CV Mosby Co. St. Louls-Toronto, Princeton,
(1986) 173pp.

13. D. Kalemba, A. Kunicka, Antibacterial and antifungal properties of essential oils. Curr. Med. Chem., 10 (2003) 813-29.

14. P. Kumar, R.P. Bhatt, L. Singh, O.P. Sati, A. Khan, A. Ahmad, Antimicrobial activities of essential oil and methanol extract of Coriaria nepalensis, Nat. Prod. Res., 25 (2011) 1074-81.

15. V. Lorenzi, A. Muselli, A.F. Bernardini, L. Berti, J.M. Page`s, L. Amaral, J.M. Bolla, Geraniol restores antibiotic activities against multidrug-resistant isolates from gram-negative species, Antimicrob. Agents Chemother., 53 (2009) 2209-11.

16. K.P. Devi, S.A. Nisha, R. Sakthivel, S.K. Pandian, Eugenol (an essential oil of clove) acts as an antibacterial agent against Salmonella typhi by disrupting the cellular membrane, J. Ethnopharmacol., 130 (2010) 107-15.

17. F.S. Solorzano-Santos, M.G. Mirande-Novales, Essential oils from aromatic herbs as antimicrobial agents, Curr. Opin. Biotechnol., 23 (2011) 1-6.

18. M. Oussalah, S. Caillet, L. Saucier, M. Lacroix, Antimicrobial effects of selected plant essential oils on the growth of a Pseudomonas putida strain isolated from meat, Meat Sci., 73 (2006) 236-44.

19. D.E. Conner, Naturally occurring compounds. Antimicrobials in foods. Davidson PM, Branen AL (eds.) Marcel Dekker, New York, 1993, 441-68 pp.

20. L. Türkmen, İrar örneklerinden izole edilen Gram negatif bakterilerin değişik antibiyotiklere duyarlılığı, İnönü Üniv. Tıp Fak. Derg., 9 (2002) 185-89.

21. T. Köhler, M. Kok, M. Michea-Hamzehpour, P. Plesiat, N. Gotoh, T. Nishino, J.C. Pechere, Multidrug efflux in intrinsic resistance to trimethoprim and sulfamethoxazole in Pseudomonas aeruginosa, Antimicrob. Agents Chemother., 40 (1996) 2288-90.

22. M. Castanheira, M.A. Toleman, R.N. Jones, F.J. Schmidt, T.R. Walsh, Molecular characterization of a beta-lactamase gene, bla $a_{G I M-1}$ encoding a new subclass of metallo-beta-lactamase, Antimicrob. Agents Chemother., 48 (2004) 46-54.

23. H.S. Sader, O.A. Reis, S. Silbert, A.C. Gales, IMPs, VIMs and SPMs: The diversity of metallo- $\beta$-lactamases produced by carbapenem-resistant Pseudomonas aeruginosa in a Brazilian hospital, Clin. Microbiol. Infect., 11 (2005) 73-76.

24. L.B. Gasink, N.O. Fishman, I. Nachamkin, W.B. Bilker, E. Lautenbach, Risk factors for and impact of infection or colonization with aztreonam-resistant Pseudomonas aeruginosa, Infect. Control Hosp. Epidemiol., 28 (2007) 1175-80.

25. O. Gutiérrez, C. Juan, E. Cercenado, F. Navarro, E. Bouza, P. Coll, J.L. Pérez, A. Oliver, Molecular epidemiology and mechanisms of carbapenem resistance in Pseudomonas aeruginosa isolates from Spanish hospitals, Antimicrob. Agents Chemother., 51 (2007) 4329.

26. D.O. Santoro, C.M. Romão, M.M. Clementino, Decreased aztreonam susceptibility among Pseudomonas aeruginosa isolates from hospital effluent treatment system and clinical samples, Int. J. Environ. Heal. Res., 22 (2012) 560-70.

27. J-M. Rodríguez-Martínez, L. Poirel, P. Nordmann, Molecular epidemiology and mechanisms of 
carbapenem resistance in Pseudomonas aeruginosa, Antimicrob. Agents Chemother., 53 (2009) 4783-88.

28. N.E. Amin, C.G. Giske, S. Jalal, B. Keijser, G. Kronvall, B. Wretlind, Carbapenem resistance mechanisms in Pseudomonas aeruginosa: alterations of porin OprD and efflux proteins do not fully explain resistance patterns observed in clinical isolates, APMIS, 113 (2005) 187-96.

29. D.M. Livermore, Of Pseudomonas, porins, pumps and carbapenems, J. Antimicrob. Chemother., 47 (2001) 247-50.

30. H. Pai, J-M. Kim, J. Kim, J.H. Lee, K.W. Choe, N. Gotoh, Carbapenem resistance mechanisms in Pseudomonas aeruginosa clinical isolates, Antimicrob. Agents Chemother., 45 (2001) 480-84.

31. J.C. Christenson, E.K. Korgenski, J.A. Daly, In vitro activity of meropenem, imipenem, cefepime and cefthazidime against Pseudomonas aeruginosa isolates from cystic fibrosis patients, J. Antimicrob. Chemother., 45 (2000) 899-901.

32. T. Gündüz, A. Arısoy, Ü. Algün, B. Özbakkaloğlu, Pseudomonas aeruginosa suşlarının aminoglikozidlere in-vitro duyarlılıkları, Ankem Derg., 18 (2004) 224-27.

33. M. Eyigör, M. Telli, Y. Tiryaki, Y. Okulu, N. Aydın, Yatan hastalardan izole edilen Pseudomonas aeruginosa suşlarının antibiyotik duyarlılıkları, ANKEM Derg., 23 (2009) 101-105.

34. L.S. Wei, W. Wee, Chemical composition and antimicrobial activity of Cymbopogon nardus citronella essential oil against systemic bacteria of aquatic animals, Iran. J. Microbiol., 5 (2013) 147-52.

35. M. Niculae, M. Spinu, C.D. Şandru, F. Brudaşca, D. Cadar, B. Szakacs, I. Scurtu, P. Bolfa, C.I. Mateş, Antimicrobial potential of some Lamiaceae essential oils against animal multiresistant bacteria, Lucrari Stiintificie, 43 (2009) 170-75 .

36. H.N. Qaralleh, M.M. Abboud, K.M. Khleifat, K.A. Tarawneh, A.Y. Althunibat, Antibacterial activity in vitro of Thymus capitatus from Jordan, Pak. J. Pharm. Sci., 22 (2009) 247-51.

37. W.A. El-Shouny, S. Magaam, Sensitivity of multi-drug resistant Pseudomonas aeruginosa isolated from surgical wound-infections to essential oils and plant extracts, W. J. Med. Sci., 4 (2009) 104-11.

38. H. Ghasemalizadeh, M. Javanmard, S. Bokharaei, Effect of thyme extract on reduction of aflatoxigenic fungi in Ahmad Aghaie Pistachio, Ann. Biol. Res., 4 (2013) 270-74.

39. G.M.S. Gonçalvest, M. Bottaro, A.C. Nilson, Effect of Thymus vulgaris essential oil on the growth of Streptococcus mutans, Rev. Ciênc. Farm. Básica Apl., 32 (2011) 375-80.

40. P. Hili, C.S. Evans, R.G. Veness, Antimicrobial action of essential oils: The effect of dimethylsulphoxide on the activity of cinnamon oil, Lett. Appl. Microbiol., 24 (1997) 269-75.

41. S. Luqman, G.R. Dwivedi, M.P. Darokar, A. Kalra, S.P.S.Khanuja Potential of rosemary oil to be used in drug resistant infections, Altern. Ther. Health Med., 13 (2007) 54-59.

42. E.B. Hirsch, V.H. Tam, Impact of multidrug-resistant Pseudomonas aeruginosa infection on patient outcomes, Expert Rev. Pharmocoecon. Outcomes Res., 10 (2010) 441-51.

43. I.C. Zampini, M.E. Arias, N. Cudmani, R.M. Ordonez, M.I. Isla, S. Moreno, Antibacterial potential of nonvolatile constituents of Rosmarinus officinalis against 37 clinical isolates of multidrug-resistant bacteria, Bol. Latinoam. Caribe Plant. Med. Aromát., 12 (2013) 201-208. 